\title{
Evaluation of Groundwater for Arsenic Contamination Using Hydrogeochemical Properties and Multivariate Statistical Methods in Saudi Arabia
}

\author{
Abdullah S. Al-Farraj, Mohammad I. Al-Wabel, Mohamed Hamza El-Saeid, \\ Ahmed H. El-Naggar, and Zaheer Ahmed
}

Soil Sciences Department, College of Food \& Agricultural Sciences, King Saud University, P.O. Box 2460, Riyadh 11451, Saudi Arabia

Correspondence should be addressed to Mohamed Hamza El-Saeid; elsaeidm@ksu.edu.sa

Received 14 June 2012; Revised 16 September 2012; Accepted 22 September 2012

Academic Editor: Stefan Tsakovski

Copyright (C) 2013 Abdullah S. Al-Farraj et al. This is an open access article distributed under the Creative Commons Attribution License, which permits unrestricted use, distribution, and reproduction in any medium, provided the original work is properly cited.

\begin{abstract}
The aim of this research is to evaluate arsenic distribution and associated hydrogeochemical parameters in 27 randomly selected boreholes representing aquifers in the Al-Kharj geothermal fields of Saudi Arabia. Arsenic was detected at all sites, with 92.5\% of boreholes yielding concentrations above the WHO permissible limit of $10 \mu \mathrm{g} / \mathrm{L}$. The maximum concentration recorded was $122 \mu \mathrm{g} / \mathrm{L}(\mathrm{SD}=29 \mu \mathrm{g} / \mathrm{L}$ skewness $=1.87)$. The groundwater types were mainly $\mathrm{Ca}^{+2}-\mathrm{Mg}^{+2}-\mathrm{SO}_{4}{ }^{-2}-\mathrm{Cl}^{-}$and $\mathrm{Na}^{+}-\mathrm{Cl}^{-}-\mathrm{SO}_{4}{ }^{-2}$, accounting for $67 \%$ of the total composition. Principal component analysis (PCA) showed that the main source of arsenic release was geothermal in nature and was linked to processes similar to those involved in the release of boron. The PCA yielded five components, which accounted for $44.1 \%, 17.0 \%, 10.1 \%, 08.4 \%$, and $06.5 \%$ of the total variance. The first component had positive loadings for arsenic and boron along with other hydrogeochemical parameters, indicating the primary sources of As mobilization are derived from regional geothermal systems and weathering of minerals. The remaining principal components indicated reductive dissolution of iron oxyhydroxides as a possible mechanism. Spatial evaluation of the PCA results indicated that this secondary mechanism of arsenic mobilization may be active and correlates positively with total organic carbon. The aquifers were found to be contaminated to a high degree with organic carbon ranging from $0.57 \mathrm{mg} / \mathrm{L}$ to $21.42 \mathrm{mg} / \mathrm{L}$ and showed high concentrations of $\mathrm{NO}_{3}{ }^{-}$ranging from $8.05 \mathrm{mg} / \mathrm{L}$ to $248.2 \mathrm{mg} / \mathrm{L}$.
\end{abstract}

\section{Introduction}

Arsenic is a toxic and carcinogenic metalloid which is geogenic in origin and has been shown to be detrimental to human health when present in the environment $[1,2]$. The major source of human exposure to arsenic is drinking water. In order to check its adverse effects the World Health Organization (WHO), the US Environmental Protection Agency (USEPA), and the European Commission have proposed guideline for arsenic in water $(10 \mu \mathrm{g} / \mathrm{L})$. Arsenic has been shown to occur in shallow aquifers above the limit in groundwaters across the world [3]. Arsenic had been shown also to occur in groundwater of arid and semiarid environments $[4,5]$. There have been reports of occurrence of arsenic in Saudi Arabian aquifers, and the arsenic contamination of groundwater could potentially have wider effects due to the use of groundwater as a main source of water in Saudi Arabia $[6,7]$.

Arsenic mobilization in groundwater is linked to geologic setting and sedimentary components, which control the geochemistry and release of As into groundwater from bedrocks. The geochemistry of groundwater is dominated by redox processes occurring at the sediment-water interface. Adsorption capacity of the mineral surfaces also depends on geochemical parameters, such as $\mathrm{pH}$, electrical conductivity (EC), ionic composition, and mineral type. Thus hydrogeochemical characteristics, such as the oxidation state of the mineral phases, and the associated cofactors affecting arsenic-containing solid phases, are responsible for arsenic mobilization. Aquifers with high arsenic content are characterized by high concentrations of bicarbonate, high $\mathrm{pH}$ and dissolved iron under reducing conditions and by sulfate, low 
$\mathrm{pH}$, and iron precipitate under oxic conditions [8,9]. Arsenic exists in two interconvertible oxidation states, As(III) and $\mathrm{As}(\mathrm{V})$. As(III), or arsenite, exists as an uncharged species $\left(\mathrm{H}_{3} \mathrm{AsO}_{3}\right)$, whereas the dominant $\mathrm{As}(\mathrm{V})$ or arsinate exists as anions $\left(\mathrm{H}_{2} \mathrm{AsO}_{4}{ }^{-}\right.$and $\left.\mathrm{HAsO}_{2}{ }^{4-}\right)$. Arsenic as a redox sensitive contaminant is proposed to obtain mobility in aquifers mainly by dissolution of $\mathrm{Fe}$ oxides of As into the aqueous phases $[10,11]$. This process is especially shown to be biologically mediated in the presence of organic matter [12]. There has also been enormous amount of research done in relation to elevated concentrations of As in geothermal fields and hot springs. High levels of As, B, Fe, Mn, and Sb occur due to mixing of cold waters with geothermal fluids and are often associated with a high total dissolved solids (TDS) [13]. The Saudi Arabian aquifers are formations existing in the Arabian shield and the Arabian shelf of the quaternary and cenozoic age. These are dozens of hot springs scattered across the country and are sometimes the subject of exploration for renewal energy [14]. A study carried by Bazuhair et al. in 1990 indicates Al-Kharj to have had hot springs, since then the hot springs have dried due to decrease in water table but the geothermal gradient exists in the deep aquifer environment [15].

Studies of arsenic hydrogeochemistry and mobilization often involve evaluation of numerous factors, and these factors can be analyzed with multivariate statistics to elucidate underlying processes. Processes like carbonate dissolution, silicate weathering, and ion exchange were found to control major-ion chemistry by using the geochemical modeling and principal component analysis [16]. Hierarchical cluster analysis (HCA) and principal components analysis (PCA) were used to elucidate aquifer geochemistry and understand evolution of hydrogeochemical characteristics of groundwater in 153 sites over a $1500 \mathrm{sq} \cdot \mathrm{km}^{2}$ area [17]. Geothermal waters from geothermal wells and hot springs were classified into two factors, one indicating the reservoir temperature distribution and the other indicating hydrogeochemical processes resulting from the $\mathrm{CO}_{2}$ pressure decrease in geothermal water during its ascent towards the ground surface [18]. Estimation of total arsenic and inorganic speciation for surface and groundwater samples was performed by using principal component analysis, cluster analysis, metalto-metal correlations, and linear regression analyses [19].

The aim of this work is to (i) report the detection of As above the WHO permissible limit in Al-Kharj geothermal fields, which has been done for the first time from this region and (ii) quantitatively evaluate the Al-Kharj area for arsenic contamination $[\mathrm{As}]_{\text {tot }}$, moreover, information on hydrogeochemical parameters [ $\mathrm{pH}, \mathrm{EC}, \mathrm{TDS}$, major anions $\left(\mathrm{HCO}_{3}{ }^{-}, \mathrm{NO}_{3}{ }^{-}, \mathrm{Cl}^{-}\right.$and $\left.\mathrm{SO}_{4}{ }^{-2}\right)$ and major cations $\left(\mathrm{Ca}^{+2}\right.$, $\mathrm{Mg}^{+2}, \mathrm{Na}^{+}$and $\mathrm{K}^{+}$)] has been obtained to characterize the quality of water as it relates to the As data. Furthermore, relevant data on trace elements ( $\mathrm{Fe}, \mathrm{Mn}, \mathrm{Li}$, and $\mathrm{Sb}$ ) to delineate arsenic geochemistry in the study area is also collected. The large dataset is subjected to multivariate statistics, using Principle Component Analysis (PCA) and Cluster Analysis (CA) techniques to determine similarities and dissimilarities in hydrogeochemical properties, and to make predictions about the As mobilization processes in aquifers of Al-Kharj region.

\section{Materials and Methods}

2.1. Geology and Hydrogeology. The studied region is AlKharj agricultural area, located southeast of Riyadh in Saudi Arabia $\left(23^{\circ} 59^{\prime} \mathrm{N} 47^{\circ} 09^{\prime} \mathrm{E}-24^{\circ} 22^{\prime} \mathrm{N} 47^{\circ} 06^{\prime \prime \prime} \mathrm{E}\right.$ ) (Figure 1). AlKharj is one of the five major agricultural regions in the country, surrounded by Wadi Dawasir, Hofuf, Gassim and Taif in the southwest, northeast, northwest, and west, respectively, of the region. The climate in this area is typically arid, with an annual precipitation of $132 \mathrm{~mm}$. Al-Kharj is considered to be a lowland with alluvium deposition. The soil type is entisol and aridisol with saline and calcareous profiles [20]. The aquifers in Al-kharj are contained within the Eocene Dammam Formation and Miocene-Pleistocene sedimentary rocks present within the stable shelf tectonic unit between the Arabian shelf and western Precambrian shield [21, 22]. Major recharge of the aquifer systems in this region has been estimated to have occurred during pluvial periods, some 25,000 to 30,000 years ago, based on isotopic methods (stable carbon, oxygen, and hydrogen) $[23,24]$. The recharge of these aquifers has been estimated to occur at a rate of $15 \%$ of the total annual rainfall that is, $100 \mathrm{~mm}$ approximately $[25,26]$.

2.2. Sampling and Analytical Methods. The groundwater sampling was collected from 27 boreholes in and around the centrally habitated Al-Kharj agricultural area (Figure 1). The boreholes were purged to about three borehole volumes before the sampling was done; the $\mathrm{pH}$ and $\mathrm{EC}$ were measured on spot to obtain instantaneous and stabilized measurements. The samples were collected in polypropylene containers which were previously cleaned and prepared with $5 \mathrm{M} \mathrm{HNO}_{3}$. The samples were analyzed for major ions $\left(\mathrm{Na}^{+}\right.$, $\mathrm{K}^{+}, \mathrm{Ca}^{+2}, \mathrm{Mg}^{+2}, \mathrm{HCO}_{3}{ }^{-}, \mathrm{Cl}^{-}$, and $\mathrm{SO}_{4}{ }^{-2}$ ) and some minor ions $\left(\mathrm{NO}_{2}{ }^{-} \mathrm{NO}_{3}{ }^{-}\right)$using the standard protocols suggested in American Public Health Association, (APHA, AWWA, WAF) [27]. Groundwater samples were filtered by $0.45 \mu \mathrm{m}$ Millipore filter paper and acidified with $2 \mathrm{~N} \mathrm{HNO}_{3}$ (Ultra pureMerck) for cation analysis and trace metal measurements. The anions $\mathrm{NO}_{2}{ }^{-} \mathrm{NO}_{3}{ }^{-}, \mathrm{Cl}^{-}$, and $\mathrm{SO}_{4}{ }^{-2}$ were analyzed using the Ion Chromatograph-Conductivity Detection (Shimadzu, LC-20AD-SP, Non-Suppressor) with Shim-pack IC-A3 (150 mmL. $4.6 \mathrm{~mm}$ I.D.) column and $8.0 \mathrm{mM} \mathrm{p}$ Hydroxybenzoic Acid: $3.2 \mathrm{mM}$ Bis-Tris as mobile phase at $1.5 \mathrm{~mL} / \mathrm{min}$ flow rate and $40^{\circ} \mathrm{C}$ using Electric Conductivity Detector (ECD). The trace element data was obtained by acidifying and subjecting to analysis using the ICP-OES (Perkin Elmer, Model 4300 DV). Sodium and Potassium were measured using flame photometry and calcium and magnesium were measured using the ICP-OES. TOC is measured by high temperature catalytic oxidation method using Shimadzu TOC-VCPN analyzer [28]. As the TOC in groundwater is mainly composed of the inorganic carbon in comparison to a relatively very minimal amount of organic carbon, nonpurgeable organic carbon (NPOC) method is used to quantitate the organic carbon. In this method first the total 


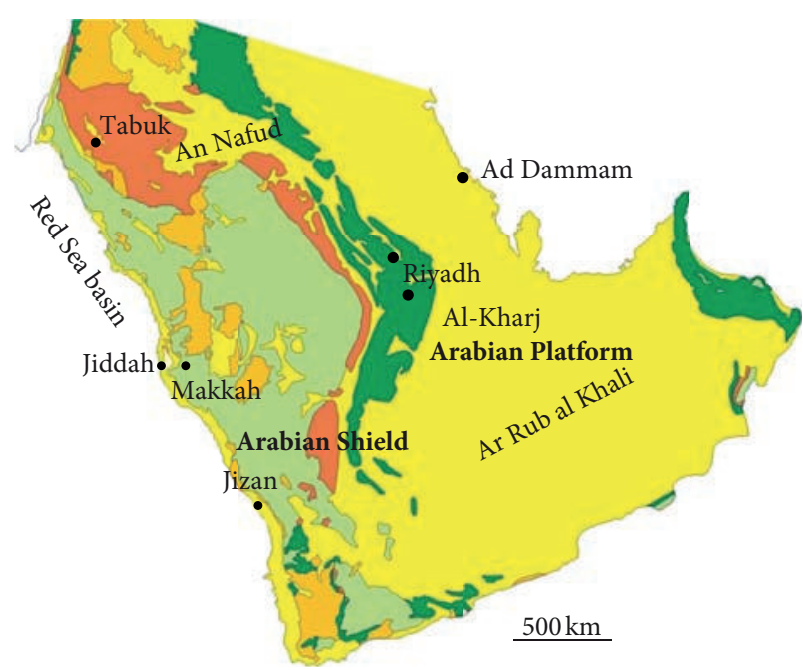

(a)

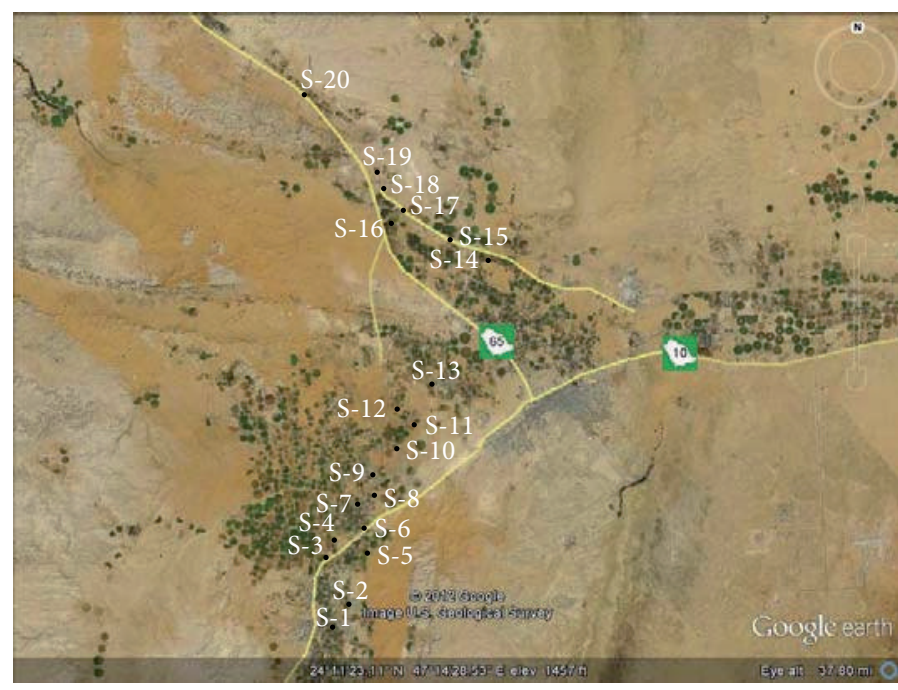

(b)

FIGURE 1: Geography of studied region of Al-Kharj Governorate in Riyadh Province East of KSA (a). The geographical layout of sedimentary rock formation in Saudi Arabia (adapted from: Saudi Geological Survey, 2008). (b) The GPS location indicating the sampling location in the Al-Kharj region in central Saudi Arabia.

inorganic carbon (TIC) is purged before any organic carbon measurement is performed; the remaining organic matter is then oxidised to $\mathrm{CO}_{2}$ and quantified as nonpurgeable organic carbon (NPOC). The concentration of $\mathrm{HCO}_{3}{ }^{-}$was determined by acid titration.

\subsection{Statistical Analysis and Data Treatment. The correla-} tion between the arsenic concentrations and physiochemical properties of groundwater was obtained in the form of Pearson correlation coefficients from the raw data. Principal component analysis (PCA) was used to reduce large number of variables to representative factors called "Principal Components". The aim was to delineate underling processes defined by parameters/variables like the physiochemical properties of groundwater, organic content, and trace element data. The components accounting for the maximum variance in the PCA output were chosen as significantly relating to the arsenic hydrogeochemistry. Proc factor procedure in the Statistical Analysis Software (SAS) was used to compute the eigenvalues and the components with eigenvalues greater than one were considered. Varimax rotation of component matrix was performed to maximize the variance between the components and simultaneously reduce the number of variables having high loading/score in each component to facilitate easy interpretation of the components. Hierarchical cluster analysis (HCA) was used as classifying tool aiming to club different sampling locations in the Al-Kharj region into few clusters with common underlying structures and to possibly explain the components obtained from PCA as detailed [29]. The clustering was done on the basis of Wards-algorithmic and shown in the form of dendrograms (Squared Euclidian distances). The multivariate analysis dataset essentially comprised of both the physiochemical properties with high numeric range and trace metal data with low numeric range, therefore before performing the PCA or HCA, data transformation/standardization was done to avoid the uneven contribution of few variables with high numeric values on the overall variance in the analysis. For effective scaling, the following transformation was applied:

$$
Z_{i j}=\frac{X_{i j}-\mu_{j}}{\sigma_{j}}
$$

where $Z_{i j}$ is the transformed variable, $X_{i j}$ is the actual variable, $\mu_{j}$ is the mean for a specific variable, and $\sigma_{j}$ in the dataset is the standard deviation, SD. This scaling method was selected as it represents the best data transformations methods for data with least number of outliers (extreme Maxima and Minima). Quality control was assured by fitting the data to normal distribution plots (not shown in paper). The variables were fairly linear, and any outliers were detected and dealt with before executing the multivariate methods. Data transformations, linear regression, and other multivariate methods were performed either by using the MS excel or the SAS statistical software (SAS Institute, Inc., 1998).

\section{Results and Discussion}

3.1. Hydrogeochemical Properties and Geothermal Tracers. The geochemical parameters for groundwater in Al-Kharj are given in Table 1. Thirteen parameters $(\mathrm{pH}$, electrical conductivity (EC), total dissolved solids (TDS), $\mathrm{Na}^{+}, \mathrm{K}^{+}, \mathrm{Ca}^{+}$, $\left.\mathrm{Mg}^{+}, \mathrm{HCO}_{3}^{-}, \mathrm{Cl}^{-}, \mathrm{SO}_{4}{ }^{2-}, \mathrm{NO}_{2}{ }^{-}, \mathrm{NO}_{3}{ }^{-}, \mathrm{TOC}\right)$, and trace elements data including $[\mathrm{As}]_{\text {tot }},[\mathrm{Fe}]_{\text {tot }}, \mathrm{Mn}$. Sb, Li, B were measured in 27 monitoring boreholes (Tables 1,2). The $\mathrm{pH}$ values ranged between 6.65 and 8.28 , which indicate a slightly acidic to slightly basic groundwater condition. Compared with the range of 6.5 to 8.5 prescribed by WHO for drinking 
TABLE 1: Hydrogeochemical parameters of Al-Kharj groundwater forming the characteristic of aquifers spread in an area of $50 \mathrm{sq} . \mathrm{Km}$.

\begin{tabular}{|c|c|c|c|c|c|c|c|c|c|c|c|c|c|}
\hline $\mathrm{S} / \mathrm{N}$ & $\mathrm{pH}$ & $\begin{array}{c}\mathrm{EC} \\
\mathrm{mS} / \mathrm{cm}\end{array}$ & $\begin{array}{l}\text { TDS } \\
\mu \mathrm{g} / \mathrm{L}\end{array}$ & $\begin{array}{c}\mathrm{Na}^{+} \\
(\mathrm{mg} / \mathrm{L})\end{array}$ & $\begin{array}{c}\mathrm{K}^{+} \\
(\mathrm{mg} / \mathrm{L}) \\
\end{array}$ & $\begin{array}{c}\mathrm{Ca}^{+} \\
(\mathrm{mg} / \mathrm{L}) \\
\end{array}$ & $\begin{array}{c}\mathrm{Mg}^{+} \\
(\mathrm{mg} / \mathrm{L})\end{array}$ & $\begin{array}{l}\mathrm{HCO}_{3}{ }^{-} \\
(\mathrm{mg} / \mathrm{L})\end{array}$ & $\begin{array}{c}\mathrm{Cl}^{-} \\
(\mathrm{mg} / \mathrm{L})\end{array}$ & $\begin{array}{l}\mathrm{NO}_{2}^{-} \\
(\mathrm{mg} / \mathrm{L})\end{array}$ & $\begin{array}{l}\mathrm{NO}_{3}{ }^{-} \\
(\mathrm{mg} / \mathrm{L})\end{array}$ & $\begin{array}{l}\mathrm{SO}_{4}{ }^{2-} \\
(\mathrm{mg} / \mathrm{L})\end{array}$ & $\begin{array}{c}\text { TOC } \\
(\mathrm{mg} / \mathrm{L})\end{array}$ \\
\hline AGW01 & 7.11 & 1.650 & 1056 & 214.8 & 1.08 & 136.5 & 56.90 & 403.5 & 94.6 & 1.35 & 24.15 & 525.8 & 14.47 \\
\hline AGW02 & 7.38 & 1.664 & 1064.96 & 286.4 & 9.24 & 150.8 & 51.78 & 333.6 & 119.85 & 4.21 & 39.5 & 676.95 & 7.69 \\
\hline AGW03 & 7.27 & 2.309 & 1477.76 & 273.6 & 12.32 & 207.2 & 85.81 & 338.5 & 188.75 & 2.76 & 24.5 & 870.25 & 9.50 \\
\hline AGW04 & 7.45 & 2.251 & 1440.64 & 291.5 & 13.43 & 194.7 & 84.50 & 348.6 & 146.65 & 1.35 & 8.05 & 1327.5 & 14.04 \\
\hline AGW05 & 7.07 & 5.113 & 3272.32 & 461.6 & 24.37 & 477.2 & 156.5 & 427.3 & 454.1 & 4.89 & 111.4 & 2726.5 & 13.00 \\
\hline AGW06 & 7.24 & 3.451 & 2208.64 & 349.1 & 12.94 & 246.2 & 94.62 & 403.1 & 297.55 & 3.78 & 57.2 & 1765.15 & 11.14 \\
\hline AGW07 & 7.51 & 2.663 & 1704.32 & 314.5 & 11.79 & 203.9 & 82.43 & 351.5 & 189.65 & 3.87 & 46.9 & 1190.2 & 9.24 \\
\hline AGW08 & 7.73 & 4.184 & 2677.76 & 361.8 & 21.89 & 304.1 & 116.1 & 327.1 & 243.3 & 4.88 & 26.5 & 3053.55 & 8.75 \\
\hline AGW09 & 6.65 & 6.030 & 3859.2 & 452.6 & 40.99 & 334.7 & 171.0 & 742 & 481.2 & 5.79 & 53.45 & 3535.4 & 21.42 \\
\hline AGW10 & 7.52 & 5.905 & 3779.2 & 466.7 & 48.25 & 339.9 & 176.3 & 429.2 & 458.35 & 13.19 & 99.6 & 3540.15 & 13.78 \\
\hline AGW11 & 7.31 & 7.236 & 4631.04 & 520.4 & 31.68 & 459.7 & 163.6 & 400.6 & 1815.27 & 1.17 & 116.64 & 3128.76 & 11.66 \\
\hline AGW 12 & 7.70 & 5.308 & 3397.12 & 259.5 & 20.39 & 461.6 & 141.9 & 244.7 & 1229.53 & 1.71 & 221.52 & 1767.37 & 9.02 \\
\hline AGW13 & 7.71 & 1.393 & 891.52 & 187.9 & 10.20 & 102.0 & 40.76 & 326.7 & 291.68 & 8.74 & 65.31 & 492.17 & 7.31 \\
\hline AGW 14 & 7.84 & 2.996 & 1917.44 & 323.5 & 21.80 & 330.8 & 58.31 & 231.1 & 360 & 10.05 & 137.70 & 1493.37 & 5.54 \\
\hline AGW15 & 7.30 & 2.912 & 1863.68 & 276.2 & 23.65 & 360.1 & 85.84 & 449.4 & 265.54 & 4.85 & 81.42 & 1657.25 & 11.96 \\
\hline AGW16 & 7.29 & 1.671 & 1069.44 & 214.8 & 12.11 & 128.4 & 52.01 & 339.3 & 204.07 & 2.33 & 27.40 & 745.17 & 7.89 \\
\hline AGW17 & 7.03 & 3.016 & 1930.24 & 265.9 & 13.97 & 211.8 & 82.25 & 449.4 & 261.47 & 1.97 & 22.06 & 1399.13 & 9.64 \\
\hline AGW 18 & 7.56 & 3.277 & 2097.28 & 290.2 & 15.55 & 304.6 & 76.77 & 297.9 & 364.92 & 5.64 & 63.53 & 1853.74 & 7.89 \\
\hline AGW19 & 7.39 & 3.226 & 2064.64 & 319.6 & 26.16 & 249.8 & 65.05 & 262.7 & 299.77 & 6.48 & 38.07 & 1418.04 & 6.82 \\
\hline AGW20 & 8.24 & 290.2 & 185728 & 104.8 & 1.95 & 16.31 & 3.75 & 24.8 & 59.28 & 0.63 & 11.54 & 101.93 & 0.574 \\
\hline AGW21 & 7.35 & 4.187 & 2679.68 & 341.4 & 24.90 & 445.6 & 85.45 & 171.9 & 361.3 & 0.30 & 179.85 & 1955 & 4.07 \\
\hline AGW22 & 7.67 & 4.644 & 2972.16 & 359.3 & 16.91 & 359.7 & 87.40 & 301.5 & 464.7 & 5.38 & 248.2 & 1834.55 & 6.76 \\
\hline AGW23 & 7.17 & 4.094 & 2620.16 & 313.2 & 21.52 & 455.2 & 93.74 & 328.9 & 377.3 & 2.79 & 136.2 & 1965.95 & 8.27 \\
\hline AGW24 & 7.40 & 2.124 & 1359.36 & 182.8 & 10.35 & 217.6 & 58.52 & 338.5 & 125.9 & 0.32 & 21.9 & 1213.3 & 7.21 \\
\hline AGW25 & 8.28 & 2.717 & 1738.88 & 290.2 & 23.86 & 363.7 & 86.17 & 578.4 & 190.85 & 3.45 & 98.55 & 1747.5 & 15.55 \\
\hline AGW26 & 7.51 & 2.090 & 1337.6 & 213.5 & 12.12 & 192.3 & 53.92 & 338.5 & 124.7 & 0.71 & 40.75 & 1139.2 & 8.08 \\
\hline AGW27 & 7.93 & 50.73 & 32467.2 & 1589.5 & 36.33 & 249.3 & 210.2 & 226.9 & 275.32 & 1.09 & 26.22 & 158.74 & 7.52 \\
\hline
\end{tabular}

water, our values were within the desirable 6.5 to 9.5 range [30]. The maximum EC was recorded as $290.2 \mu \mathrm{S} / \mathrm{cm}$, and the minimum was $1.39 \mu \mathrm{S} / \mathrm{cm}$. The maximum TDS value was 2,06,042 mg/L, and the minimum was $989.11 \mathrm{mg} / \mathrm{L}$. According to the TDS classification, $33.3 \%$ of the sampling sites were fresh water (TDS < 2000), 59.2\% of the sampling sites were brackish water $(2000<$ TDS < 10000), and $7.4 \%$ were saline (TDS > 10000) [31]. The TDS values were markedly higher compared with reported values from the Arabian shield aquifers situated in Wadi Marwani, central western Saudi Arabian indication of geothermal activity [32]. The cations in considerably high concentrations were $\mathrm{Na}^{+}$and $\mathrm{Ca}^{+}$, which ranged from $104.8 \mathrm{mg} / \mathrm{L}$ to $1589.5 \mathrm{mg} / \mathrm{L}$, and $136.5 \mathrm{mg} / \mathrm{L}$ to $249.3 \mathrm{mg} / \mathrm{L}$, respectively. $\mathrm{K}^{+}$and $\mathrm{Mg}^{+}$were in the range of $1.08 \mathrm{mg} / \mathrm{L}$ to $36.33 \mathrm{mg} / \mathrm{L}$, and $56.9 \mathrm{mg} / \mathrm{L}$ to $210.2 \mathrm{mg} / \mathrm{L}$, respectively. The anions in considerably high concentrations were $\mathrm{SO}_{4}{ }^{-}$and $\mathrm{HCO}_{3}{ }^{-}$, which ranged from $24.8 \mathrm{mg} / \mathrm{L}$ to $742 \mathrm{mg} / \mathrm{L}$, and $101.93 \mathrm{mg} / \mathrm{L}$ to $3535.4 \mathrm{mg} / \mathrm{L}$, respectively. The other cations in the study $\left(\mathrm{Cl}^{-}, \mathrm{NO}_{2}{ }^{-}\right.$, and $\left.\mathrm{NO}_{3}{ }^{-}\right)$were in the range of 59.28-1815.27, 0.3-13.19, 8.05-221.52 mg/L, respectively. The nitrate and nitrite concentrations appeared to be typical, compared with studies reported from other regions in Saudi Arabia [33]. The tendency for $\mathrm{NO}_{2}{ }^{-}$and
$\mathrm{NO}_{3}{ }^{-}$to increase, due to agricultural activity has been demonstrated in Saudi Arabia and other countries [34, 35]. A brief evaluation of the dataset suggests that cations $\mathrm{Ca}^{+}$ and $\mathrm{Na}^{+}$were quantitatively more abundant than cations $\mathrm{K}^{+}$ and $\mathrm{Mg}^{+}$. Likewise, anions $\mathrm{Cl}^{-}$and $\mathrm{SO}_{4}{ }^{2-}$ were quantitatively more abundant than anions $\mathrm{HCO}_{3}{ }^{-}$and $\mathrm{NO}_{3}{ }^{-}$. Nitrate and Nitrite were detected at all the sites, but nitrite is quantitatively less than the nitrate, high levels of nitrate quantities reflect intensive use of fertilizers in the studied region. A careful study of the major ion chemistry of the collected groundwater can reveal the flow path of the aquifer because high $\mathrm{Ca}^{+}: \mathrm{Mg}^{+}$ratios, low $\mathrm{SO}_{4}{ }^{2-}$, and high $\mathrm{HCO}_{3}{ }^{-}$occur at the recharge zones. Conversely, the opposite conditions generally prevail in discharge zones. In addition, the flow pattern of the aquifer system in the Dammam Formation is believed to be in the upward and northerly direction $[21,36]$.

Arsenic was detected at all the sites, with $92.5 \%$ of the boreholes showing concentrations above the WHO permissible limit of $10 \mu \mathrm{g} / \mathrm{L}$, with a maximum of $122 \mu \mathrm{g} / \mathrm{L}$ [37]. Manganese and iron were linked to arsenic release from the bedrock interface in the aquifer system. Manganese was detected in the range of $6 \mu \mathrm{g} / \mathrm{L}$ to $14 \mu \mathrm{g} / \mathrm{L}$, and iron was detected within the range of $129 \mu \mathrm{g} / \mathrm{L}$ to $236 \mu \mathrm{g} / \mathrm{L}$. 
TABLE 2: Trace element data for Al-Kharj groundwater forming the characteristic of aquifers spread in an area of 50 sq. $\mathrm{Km}$.

\begin{tabular}{|c|c|c|c|c|c|c|}
\hline $\mathrm{S} / \mathrm{N}$ & $\begin{array}{c}\mathrm{Li} \\
(\mathrm{mg} / \mathrm{L})\end{array}$ & $\begin{array}{c}\mathrm{Sb} \\
(\mathrm{mg} / \mathrm{L})\end{array}$ & $\begin{array}{c}\mathrm{Mn} \\
(\mu \mathrm{g} / \mathrm{L})\end{array}$ & $\begin{array}{l}{[\mathrm{As}]_{\mathrm{tot}}} \\
(\mu \mathrm{g} / \mathrm{L})\end{array}$ & $\begin{array}{c}\mathrm{Fe} \\
(\mu \mathrm{g} / \mathrm{L})\end{array}$ & $\begin{array}{c}\text { B } \\
(\mathrm{mg} / \mathrm{L})\end{array}$ \\
\hline AGW01 & 0.049 & 0.012 & 6 & 31 & 129 & 0.0252 \\
\hline AGW02 & 0.062 & 0.272 & 1 & 2 & 139 & 0.445 \\
\hline AGW03 & 0.071 & 0.317 & 2 & 6 & 89 & 0.349 \\
\hline AGW04 & 0.074 & 0.556 & 3 & 17 & 249 & 0.388 \\
\hline AGW05 & 0.138 & 1.053 & 3 & 14 & 93 & 1.833 \\
\hline AGW06 & 0.081 & 1.051 & 1 & 25 & 49 & 0.548 \\
\hline AGW07 & 0.074 & 0.861 & 3 & 23 & 65 & 0.752 \\
\hline AGW08 & 0.125 & 0.539 & 13 & 20 & 173 & 1.013 \\
\hline AGW09 & 0.137 & 0.372 & 1 & 31 & 88 & 2.272 \\
\hline AGW10 & 0.203 & ND & 11 & 55 & 76 & 2.056 \\
\hline AGW11 & 0.151 & 0.661 & 4 & 88 & 75 & 1.350 \\
\hline AGW12 & 0.103 & 0.413 & 7 & 122 & 203 & 0.284 \\
\hline AGW13 & 0.052 & ND & 1 & 73 & 56 & 0.257 \\
\hline AGW14 & 0.123 & ND & 3 & 38 & 85 & 0.702 \\
\hline AGW15 & 0.123 & 0.776 & 6 & 30 & 560 & 0.601 \\
\hline AGW16 & 0.062 & 0.440 & 1 & 27 & 67 & 0.293 \\
\hline AGW17 & 0.093 & 0.599 & 7 & 25 & 145 & 0.567 \\
\hline AGW18 & 0.091 & 0.595 & 2 & 15 & 60 & 0.446 \\
\hline AGW19 & 0.121 & 1.085 & 14 & 17 & 236 & 0.515 \\
\hline AGW20 & 0.009 & 0.406 & 2 & 16 & 68 & 0.459 \\
\hline AGW21 & 0.107 & 0.115 & 1 & 16 & 95 & 0.537 \\
\hline AGW22 & 0.085 & 0.155 & 1 & 17 & 95 & 0.537 \\
\hline AGW23 & 0.130 & 1.158 & 1 & 20 & 59 & 0.663 \\
\hline AGW24 & 0.140 & 0.089 & ND & 18 & 42 & 0.290 \\
\hline AGW25 & 0.114 & 0.107 & 4 & 22 & 69 & 0.532 \\
\hline AGW26 & 0.063 & 0.003 & 1 & 26 & 256 & 0.327 \\
\hline AGW27 & 0.210 & 0.003 & 5 & 75 & 151 & 4.254 \\
\hline
\end{tabular}

"ND: below the detection level.

This indicated that iron was quantitatively more abundant than manganese in the aquifer strata, a characteristic of the minerals present, and part of the mineralization process. Boron was detected at all the sampling sites, with a range of $25-4254 \mu \mathrm{g} / \mathrm{L}$. Lithium concentrations were detected between $9-210 \mu \mathrm{g} / \mathrm{L}$, while antimony was detected in the range of $0-1158 \mu \mathrm{g} / \mathrm{L}$. The detection of high concentrations of boron, antimony, lithium, and a correlation coefficient of $R^{2}=0.6$ between boron and arsenic indicates the presence of geothermal activity in the region [13]. Also the correlation of lithium and boron is 0.56 indicating the presence of geothermal activity in the area as boron and lithium are considered as geothermal tracers [13]. Piper diagrams traditionally have been used to understand groundwater chemistry processes, and to predict the nature and origin of water types. Figure 2 shows piper diagrams with respect to major sedimentary facies. Groundwater mainly was composed of $\mathrm{Ca}^{+2}-\mathrm{Mg}^{+2}$ $\mathrm{SO}_{4}{ }^{-2}-\mathrm{Cl}^{-}$and $\mathrm{Na}^{+}-\mathrm{Cl}^{-}-\mathrm{SO}_{4}{ }^{-2}$ types, accounting for $67 \%$ of the total. Two major types of hydrochemical facies accounting for $67 \%$ and remaining to $33 \%$ of the hydrochemical facies may reflect a distinct fracture pattern in the lithology of the region [15] and could determine the arsenic release mechanism.

3.2. Identification of Main Processes Causing the Release of Arsenic. The principal component analysis of standardized parameters resulted in five components with eigenvalues of $7.0518,2.7257,1.6086,1.3456,1.0368$, accounting for $44.1 \%, 17.0 \%, 10.1 \%, 08.4 \%$, and $06.5 \%$ of the total variance, respectively (Tables 3,4 ). Although PCA can provide as many components as the number of variables, only those components with eigenvalues greater than one were considered. The first component had positive loading for all parameters, except for $\mathrm{pH}$ and $\mathrm{Fe}$. The second component had a positive loading for all parameters, except $\mathrm{pH}$, TDS, $\mathrm{Ca}^{+} \mathrm{Cl}^{-}, \mathrm{NO}_{3}{ }^{-}$ $\mathrm{Mn}$, and As. The third component had a positive loading for all parameters, except TDS, $\mathrm{Na}^{+}, \mathrm{K}^{+}, \mathrm{Ca}^{+}, \mathrm{Mg}^{+}, \mathrm{HCO}_{3}^{-}$, $\mathrm{Cl}^{-}, \mathrm{NO}_{3}{ }^{-}$, TOC, and As. The fourth component had positive loading for all parameters, except TDS, $\mathrm{Mg}^{+}, \mathrm{HCO}_{3}^{-}, \mathrm{Cl}^{-}$, $\mathrm{NO}_{3}{ }^{-}$, TOC $\mathrm{Mn}, \mathrm{As}$ and $\mathrm{Fe}$, and the fifth component had positive loading for all parameters, except TDS, $\mathrm{Na}^{+}, \mathrm{K}^{+}$, $\mathrm{Ca}^{+}, \mathrm{NO}_{3}{ }^{-}, \mathrm{SO}_{4}{ }^{-}, \mathrm{Mn}, \mathrm{Fe}$, and $\mathrm{B}$. The first component (PC1) has a positive loading for arsenic and boron with negative loadings for Fe. This indicated that this component accounted for the maximum variance of the PCA and was representative of arsenic and boron release due to geothermal systems and mineral weathering [38-40]. This can be confirmed by the observation that boron correlated with $\mathrm{Na}^{+}$and $\mathrm{SO}_{4}{ }^{-2}$, with values of 0.82 and 0.71 , respectively. Also arsenic correlation with iron is poor $\left(R^{2}=0.0018\right)$ and $\mathrm{Fe}$ has a negative factor loading in the PC1. Moreover, arsenic has been shown to be relatively soluble in hot and warm hydrothermal fluids [41]. The subsequent principal components supported this interpretation.

The second component (PC2) indicates the reductive dissolution of iron oxides as a possible mechanism. This component had a maximum loading for TOC and $\mathrm{HCO}_{3}{ }^{-}$and a positive high loading for Fe. Spatial evaluation indicated that a secondary mechanism of mobilization could be active and has a positive correlation with TOC. This mechanism relates to biologically mediated arsenic release due to the reductive dissolution of iron containing oxide from the mineral phase in the presence of organic matter [12]. Sites $6,8,15,16,17$, 18 , and 19 , which constituted $25 \%$ of the total composition, had an $R^{2}$ of 0.53 . The presence of freely dissolved iron in groundwater obtained from agricultural areas of the AlKharj region has been shown in other studies [42]. The two prominent types of mechanisms occurring in the subsurface sediments can be understood further by cluster analysis. Cluster analysis of the sampling sites with regard to As and $B$ resulted in two distinct structural groupings, sites 2,18 , $3,25,16,23,4,12$, and 13, and another group of 6,20 , $21,24,19,17,15,7,14$, and 22 (Figure 3). The presence of two distinct clusters in the pattern for As and B indicates the underlying communality in relation to hydrogeochemical properties. The deviation from a single main cluster could be due to the $\mathrm{K}^{+}$and $\mathrm{PO}_{4}{ }^{-3}$ present in the aquifer, as Al-Kharj is an agricultural region and has a considerable amount of fertilizer input and from leaching of fertilizers and pesticides 
TABLE 3: Pearson correlation matrix for the hydrochemical properties indicating the extent of effect of parameters.

\begin{tabular}{|c|c|c|c|c|c|c|c|c|c|c|}
\hline & $\mathrm{pH}$ & $\mathrm{EC}(\mu \mathrm{S} / \mathrm{cm})$ & $\mathrm{Na}^{+}$ & $\mathrm{K}^{+}$ & $\mathrm{Ca}^{+}$ & $\mathrm{Mg}^{+}$ & $\mathrm{HCO}_{3}{ }^{-}$ & $\mathrm{Cl}^{-}$ & $\mathrm{HNO}_{3}{ }^{-}$ & $\mathrm{SO}_{4}^{-}$ \\
\hline $\mathrm{EC}(\mu \mathrm{S} / \mathrm{cm})$ & 0.469 & & & & & & & & & \\
\hline $\mathrm{Na}^{+}$ & 0.113 & -0.026 & & & & & & & & \\
\hline $\mathrm{K}^{+}$ & -0.116 & -0.242 & 0.561 & & & & & & & \\
\hline $\mathrm{Ca}^{+}$ & -0.174 & -0.411 & 0.207 & 0.630 & & & & & & \\
\hline $\mathrm{Mg}^{+}$ & -0.210 & -0.272 & 0.725 & 0.826 & 0.617 & & & & & \\
\hline $\mathrm{HCO}_{3}^{-}$ & -0.519 & -0.520 & -0.013 & 0.374 & 0.241 & 0.381 & & & & \\
\hline $\mathrm{Cl}^{-}$ & -0.101 & -0.152 & 0.153 & 0.422 & 0.614 & 0.526 & 0.076 & & & \\
\hline $\mathrm{HNO}_{3}{ }^{-}$ & 0.105 & -0.208 & -0.014 & 0.297 & 0.735 & 0.244 & -0.098 & 0.531 & & \\
\hline $\mathrm{SO}_{4}^{-}$ & -0.347 & -0.344 & 0.014 & 0.706 & 0.720 & 0.607 & 0.521 & 0.502 & 0.370 & \\
\hline As (ug/L) & 0.183 & -0.055 & 0.343 & 0.349 & 0.270 & 0.485 & -0.049 & 0.709 & 0.347 & 0.108 \\
\hline
\end{tabular}
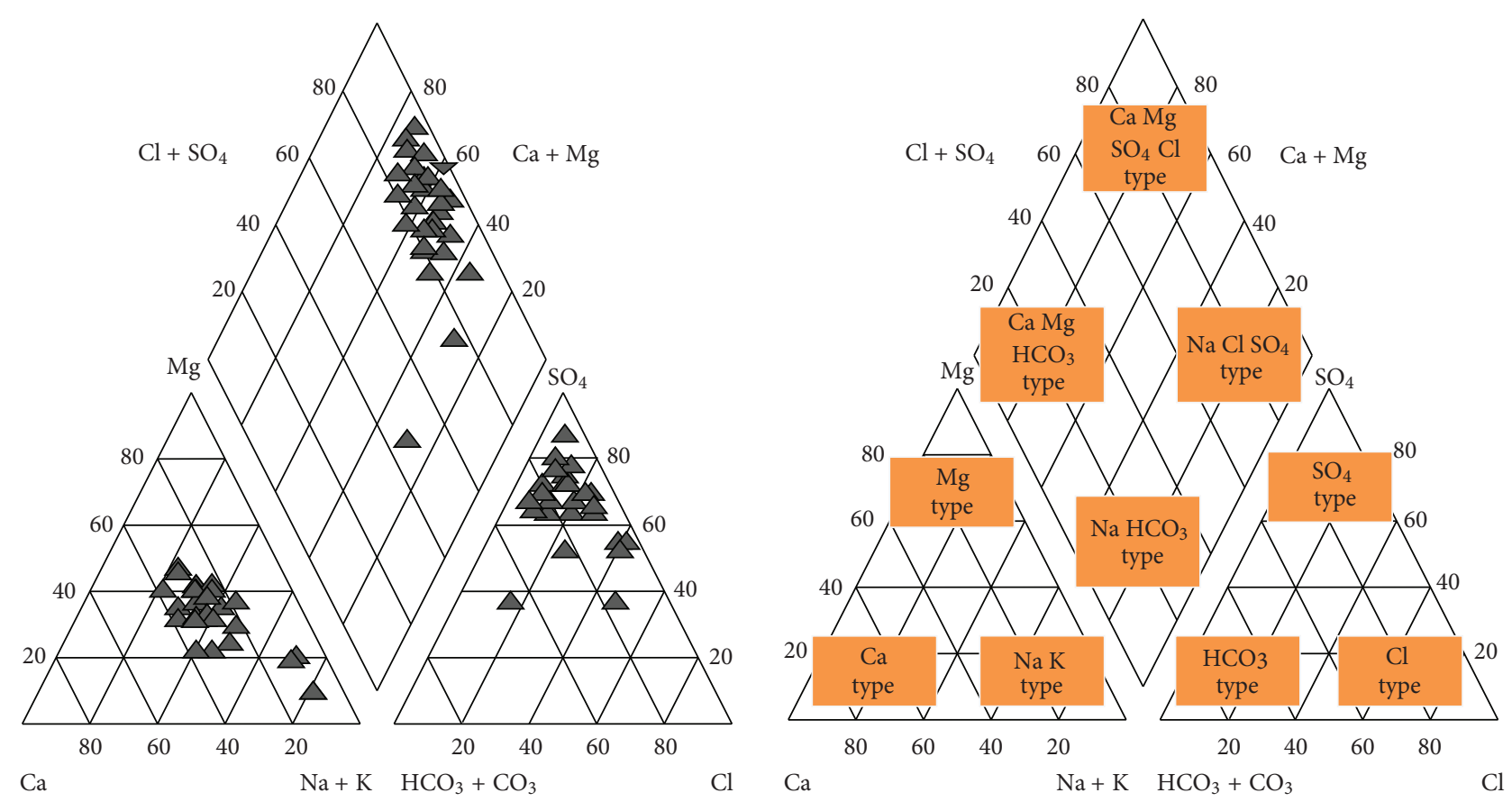

FIGURE 2: Piper diagram displaying the major ions present in the groundwater, indication of $\mathrm{Ca}^{+2}-\mathrm{Mg}^{+2}-\mathrm{SO}_{4}^{-2}-\mathrm{Cl}^{-}$and $\mathrm{Na}^{+}-\mathrm{Cl}^{-}-\mathrm{SO}_{4}{ }^{-2}$ type of water in the aquifer environment.

added from anthropogenic sources, this could impact the subsurface geochemistry. This dendrogram can represent the PC1 obtained from the principal component analysis. The second dendrogram in Figure 3 refers to the clustering of sites with respect to As, $\mathrm{Fe}, \mathrm{Mn}, \mathrm{TOC}, \mathrm{NO}_{3}{ }^{-}, \mathrm{HCO}_{3}{ }^{-}$. The dendrogram provides numerous unclear clusters and the level of similarity lying in the subclusters is less (Similarity expressed as $\%$ on $y$-axis of the dendrograms), indicating the interaction of various factors involved along with the process of mobilization of arsenic through reductive dissolution of ferrous oxyhydroxide. This dendrogram can represent the PC2, PC3, PC4, and PC5 components. While PC1 and PC2 are being recognized as the main components and this fits well with the water type classification which is mainly two types $\mathrm{Ca}^{+2}-\mathrm{Mg}^{+2}-\mathrm{SO}_{4}{ }^{-2}-\mathrm{Cl}^{-}$and $\mathrm{Na}^{+}-\mathrm{Cl}^{-}-\mathrm{SO}_{4}{ }^{-2}$. While cluster analysis can be used to exactly extract clusters and relate to principal components, in our case the commonalities in the clusters obtained from the cluster analysis have been used to relate to the PCA output. More exact relation can probably be obtained by having more explicit details pertinent to the regions geology and lithology which unfortunately is not available for this kind of research from Al-Kharj region, Saudi Arabia so far. Also this paper does not undertake the speciation of arsenic to arsenite As(III) and arsenate As(V) which could have helped in relating the data more to the groundwater chemistry of the region. Also the components PC3, PC4, PC5 can in principle be ignored as they account for mere $10.1 \%, 8.4 \%$, and $6.5 \%$ of the total variance and their eigenvalues are far less than the average of the five eigenvalues. 
TABLE 4: Loading of physiochemical parameters in the principal components expressing the geochemical processes.

\begin{tabular}{lccccc}
\hline & PC1 & PC2 & PC3 & PC4 & PC5 \\
\hline $\mathrm{pH}$ & -0.071 & -0.325 & 0.362 & 0.117 & 0.313 \\
$\mathrm{TDS}$ & 0.361 & -0.116 & -0.098 & -0.013 & -0.077 \\
$\mathrm{Na}^{+}$ & 0.340 & 0.041 & -0.012 & 0.175 & -0.148 \\
$\mathrm{~K}^{+}$ & 0.336 & 0.031 & 0.210 & 0.067 & -0.054 \\
$\mathrm{Ca}^{+}$ & 0.282 & -0.253 & -0.117 & 0.003 & -0.307 \\
$\mathrm{Mg}^{+}$ & 0.360 & 0.046 & -0.067 & -0.081 & 0.024 \\
$\mathrm{HCO}_{3}{ }^{-}$ & 0.155 & 0.456 & -0.105 & -0.104 & 0.273 \\
$\mathrm{Cl}^{-}$ & 0.247 & -0.301 & -0.226 & -0.255 & 0.208 \\
$\mathrm{NO}_{2}{ }^{-}$ & 0.124 & 0.028 & 0.551 & 0.357 & 0.250 \\
$\mathrm{NO}_{3}{ }^{-}$ & 0.158 & -0.445 & -0.109 & 0.129 & -0.072 \\
$\mathrm{SO}_{4}{ }^{-}$ & 0.355 & 0.050 & 0.058 & 0.072 & -0.126 \\
$\mathrm{TOC}^{-}$ & 0.185 & 0.416 & -0.087 & -0.219 & 0.278 \\
$\mathrm{Mn}^{\mathrm{As}}$ & 0.105 & -0.009 & 0.578 & -0.327 & -0.109 \\
$\mathrm{Fe}$ & 0.145 & -0.304 & -0.023 & -0.381 & 0.568 \\
$\mathrm{~B}$ & -0.029 & 0.332 & 0.265 & -0.622 & -0.403 \\
\hline
\end{tabular}

3.3. Miscellaneous Processes. While reductive dissolution of As from arsenopyrites/Fe oxihydroxides is a biotic process, the competitive effect of direct carbonate ions in ground water is proposed to be another major abiotic process of As release [43]. The bicarbonate exhibits poor correlation with total As concentration indicating that direct competitive effect of bicarbonate on As for adsorbtion site is not a process occurring in As mobilization at Al-Kharj region (Figure 4). The presence of nitrate in anoxic waters is linked to the chemolithotropic dinitrification of arsenite to arsenate. This is believed to facilitate the anoxic oxidation of ferrous iron $\mathrm{Fe}(\mathrm{II})$ and the arsenite As(III) to ferric iron $\mathrm{Fe}(\mathrm{III})$ and less mobile arsenate $\mathrm{As}(\mathrm{V})$ [44]. This process does not appear to be occurring in the largely anoxic sulfidic waters of the Al-Kharj aquifers as nitrate and arsenic do not exhibit a significant negative correlation as would be expected by this process (Figure 4). The nitrate presence should facilitate the process of oxidation of arsenite to arsenate which is relatively less mobile and reprecipitated to the Fe hydroxides, if this process would occur the nitrate correlates negatively to the total As content, but that does not seem to be the case in the Al-Kharj aquifers.

3.4. Geothermometry to Access Correlation of As Release to Temperature Gradient. A direct comparison of the temperature from wellheads has in many cases shown low correlations comparing the arsenic levels with the temperature gradient $[13,16,45]$. And therefore most of the researches have relied on understanding the mobilization of arsenic through hydrogeochemical data, this paper does the same. It can be realized that there are divers geothermometric technique like $\mathrm{Na} / \mathrm{K}$ geothermometer, $\mathrm{Na} / \mathrm{Li}$ geothermometer, and $\mathrm{SiO}_{2}$ geothermometer which are used to assess the exact temperature of geothermal waters at the point of origin, but these techniques depend on the hydrochemical properties and have

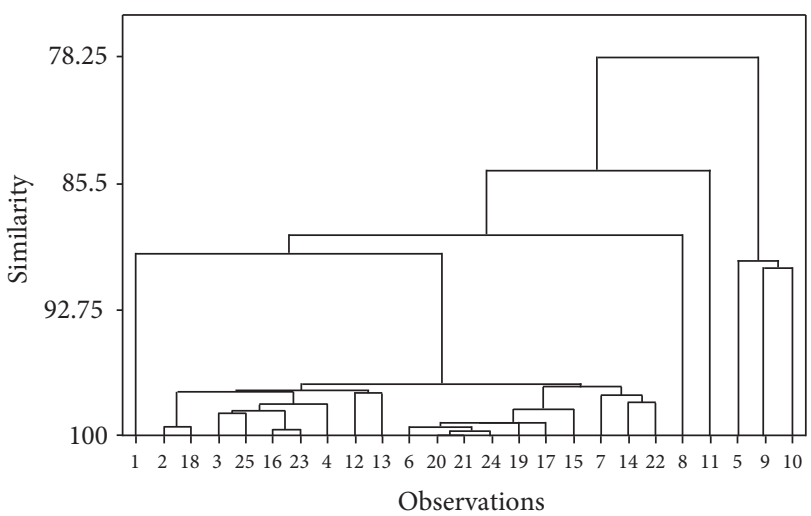

(a)

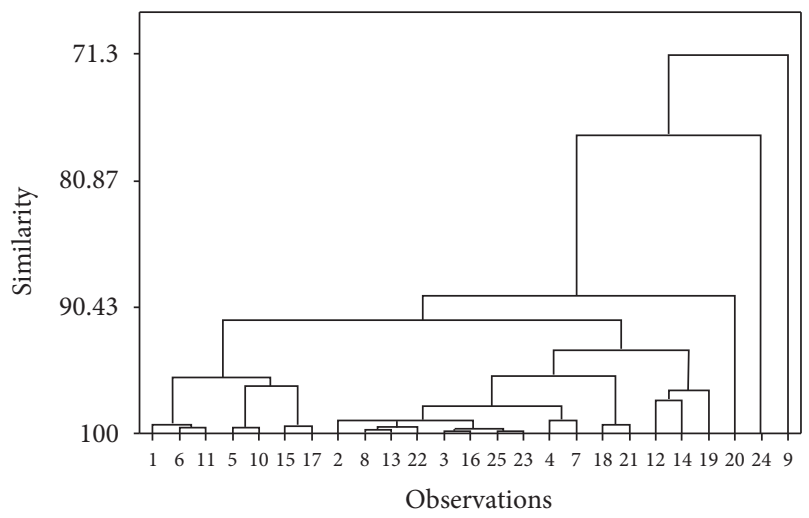

(b)

FIgURE 3: Multivariate statistical analysis of Al-Kharj groundwater data: (a) cluster analysis with respect to As and $\mathrm{B}$ (b) cluster analysis with respect to $\mathrm{Fe}, \mathrm{As}, \mathrm{Mn}, \mathrm{TOC}, \mathrm{HNO}_{3}{ }^{-}$.

been largely restricted in efficiency of use [46]. Therefore this paper does not attempt to report or enhance on the role of temperature in arsenic mobilization. A more precise hydrochemical characterization of mixing between thermal and nonthermal groundwater as performed by Navarro et al., 2011 and Piqué et al., 2010 is suggested to an enhanced understanding of the geochemistry, geothermal mechanisms, lithology, and geomorphology in Al-Kharj geothermal fields $[13,45]$.

\section{Conclusions}

Characterization of hydrogeochemistry and arsenic contamination in geothermal systems of Al-Kharj aquifers in Saudi Arabia has been done to understand the primary processes causing the arsenic mobilization into the groundwater. The main processes responsible are geothermal, and this has been established with different geothermal tracers and geostatistics. The reductive dissolution of arsenic bearing minerals could also be a process occurring, this has been observed and concluded as the aquifer systems in Al-Kharj region show significant amounts of TOC content and experience a slow water moment with low recharge rates, which is why the system has only two major water types classification. The processes 


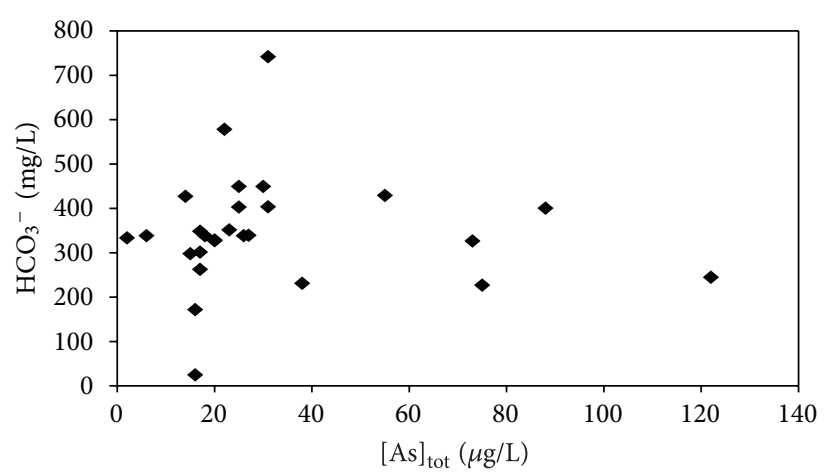

(a)

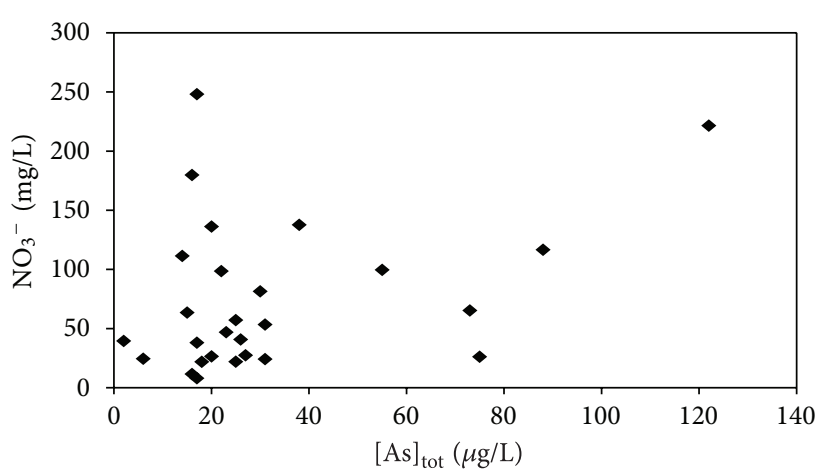

(b)

FIGURE 4: Bicarbonate and nitrification corresponding to correlation with the total arsenic $[\mathrm{As}]_{\mathrm{tot}} R^{2}\left(\mathrm{HCO}_{3}{ }^{-}\right)=0.002 ; R^{2}\left(\mathrm{NO}_{3}^{-}\right)=0.120$.

like the mobilization due to competitive effects of carbonate ions to As and chemolithotropic dinitrification of arsenite to less mobile arsenate can be ruled out in this system which is characteristically anoxic and high in sulphate levels. A thorough investigation though is needed to comprehensively study this system which may include profiling mineralogical and morphological patterns of the sedimentary rocks and aquifer system along with hydrogeochemical studies.

\section{Acknowledgment}

This project was supported by Research Center, College of Food \& Agricultural Sciences, Deanship of Scientific Research, King Saud University.

\section{References}

[1] C. O. Abernathy, D. J. Thomasy, and R. L. Calderon, "Toxicity and risk assessment of trace elements. Health effects and risk assessment of arsenic," American Society for Nutrition, vol. 133, pp. 1536-1538, 2003.

[2] M. S. Bloom, E. F. Fitzgerald, K. Kim, I. Neamtiu, and E. S. Gurzau, "Spontaneous pregnancy loss in humans and exposure to arsenic in drinking water," International Journal of Hygiene and Environmental Health, vol. 213, no. 6, pp. 401-413, 2010.

[3] J. Matschullat, "Arsenic in the geosphere-a review," Science of the Total Environment, vol. 249, no. 1-3, pp. 297-312, 2000.

[4] B. R. Scanlon, J. P. Nicot, R. C. Reedy, D. Kurtzman, A. Mukherjee, and D. K. Nordstrom, "Elevated naturally occurring arsenic in a semiarid oxidizing system, Southern High Plains aquifer, Texas, USA," Applied Geochemistry, vol. 24, no. 11, pp. 2061-2071, 2009.

[5] H. B. Nicolli, J. Bundschuh, J. W. García, C. M. Falcón, and J. S. Jean, "Sources and controls for the mobility of arsenic in oxidizing groundwaters from loess-type sediments in arid/semiarid dry climates-evidence from the Chaco-Pampean plain (Argentina)," Water Research, vol. 44, no. 19, pp. 5589-5604, 2010.

[6] M. Hussain, S. M. Ahmed, and W. Abderrahman, "Cluster analysis and quality assessment of logged water at an irrigation project, eastern Saudi Arabia," Journal of Environmental Management, vol. 86, no. 1, pp. 297-307, 2008.
[7] M. Sadiq and I. Alam, "Arsenic chemistry in a ground water aquifer from the eastern province of Saudi Arabia," Water, Air, and Soil Pollution, vol. 89, no. 1-2, pp. 67-76, 1996.

[8] P. Bose and A. Sharma, "Role of iron in controlling speciation and mobilization of arsenic in subsurface environment," Water Research, vol. 36, no. 19, pp. 4916-4926, 2002.

[9] H. Guo, B. Zhang, G. Wang, and Z. Shen, "Geochemical controls on arsenic and rare earth elements approximately along a groundwater flow path in the shallow aquifer of the Hetao Basin, Inner Mongolia," Chemical Geology, vol. 270, no. 1-4, pp. 117-125, 2010.

[10] J. M. McArthur, P. Ravenscroft, S. Safiulla, and M. F. Thirlwall, "Arsenic in groundwater: testing pollution mechanisms for sedimentary aquifers in Bangladesh," Water Resources Research, vol. 37, no. 1, pp. 109-117, 2001.

[11] C. F. Harvey, C. H. Swartz, A. B. M. Badruzzaman et al., "Arsenic mobility and groundwater extraction in Bangladesh," Science, vol. 298, no. 5598, pp. 1602-1606, 2002.

[12] F. S. Islam, A. G. Gault, C. Boothman et al., "Role of metalreducing bacteria in arsenic release from Bengal delta sediments," Nature, vol. 430, no. 6995, pp. 68-71, 2004.

[13] A. Navarro, X. Font, and M. Viladevall, "Geochemistry and groundwater contamination in the La Selva geothermal system (Girona, Northeast Spain)," Geothermics, vol. 40, pp. 275-285, 2011.

[14] H. M. Taleb, "Barriers hindering the utilisation of geothermal resources in Saudi Arabia," Energy for Sustainable Development, vol. 13, no. 3, pp. 183-188, 2009.

[15] A. A. Bazuhair, M. T. Hussein, and M. S. Hamza, "Comparative hydrochemical study of water springs in Saudi Arabia," International Journal of Water Resources Development, vol. 6, no. 2, pp. 143-150, 1990.

[16] M. A. Halim, R. K. Majumder, S. A. Nessa et al., "Evaluation of processes controlling the geochemical constituents in deep groundwater in Bangladesh: spatial variability on arsenic and boron enrichment," Journal of Hazardous Materials, vol. 180, no. 1-3, pp. 50-62, 2010.

[17] V. Cloutier, R. Lefebvre, R. Therrien, and M. M. Savard, "Multivariate statistical analysis of geochemical data as indicative of the hydrogeochemical evolution of groundwater in a sedimentary rock aquifer system," Journal of Hydrology, vol. 353, no. 3-4, pp. 294-313, 2008.

[18] Q. Guo, Y. Wang, and W. Liu, "Hydrogeochemistry and environmental impact of geothermal waters from Yangyi of 
Tibet, China," Journal of Volcanology and Geothermal Research, vol. 180, no. 1, pp. 9-20, 2009.

[19] J. Ahmed Baig, T. Gul Kazi, A. Qadir Shah et al., "Speciation and evaluation of Arsenic in surface water and groundwater samples: a multivariate case study," Ecotoxicology and Environmental Safety, vol. 73, no. 5, pp. 914-923, 2010.

[20] I. I. Bashour, A. S. Al-Mashhady, J. Devi Prasad, T. Miller, and M. Mazroa, "Morphology and composition of some soils under cultivation in Saudi Arabia," Geoderma, vol. 29, no. 4, pp. 327-340, 1983.

[21] A. Mukhopadhyay, J. Al-Sulaimi, E. Al-Awadi, and F. AlRuwaih, "An overview of the Tertiary geology and hydrogeology of the northern part of the Arabian Gulf region with special reference to Kuwait," Earth-Science Reviews, vol. 40, no. 3-4, pp. 259-295, 1996.

[22] M. M. Lababidi and A. N. Hamdan, Preliminary Lithostratigraphic Correlation Study in OAPEC Member Countries, Organization of Arab Petroleum Exporting Countries, Kuwait, 1985.

[23] J. G. Pike, "Groundwater resources and development in the central region of the Arabian Gulf," in Memoirs of the 18th Congress IAH Hydrogeology in the Services of Man, pp. 46-55, Cambridge, UK, 1985.

[24] O. Quinn, "Regional hydrogeological evaluation of the Najd," Open-file Report CCEWR 48-86, Public Authority for Water Resources, Sultanate of Oman, 1986.

[25] P. Beaument, "Water resources and their management in the Middle East," in Change and Development in the Middle East, J. I. Clarke and H. Bowen-Jones, Eds., pp. 41-72, Methuen, London, UK, 1981.

[26] J. G. Pike, "Groundwater resources development and the environment in the Central Region of the Arabian Gulf," Water Resources Development, pp. 115-132, 1983.

[27] APHA, AWWA, and WEF, Standard Methods for the Examination of Water and Waste Water, 21st edition, 2005.

[28] Y. Sugimura and Y. Suzuki, "A high-temperature catalytic oxidation method for the determination of non-volatile dissolved organic carbon in seawater by direct injection of a liquid sample," Marine Chemistry, vol. 24, no. 2, pp. 105-131, 1988.

[29] J. C. Davis, Statistics and Data Analysis in Geology, John Wiley \& Sons, New York, NY, USA, 1986.

[30] World Health Organization (WHO), Guidelines for Drinking Water Quality, vol. 1, Recommendations, Geneva, Switzerland, 1993.

[31] G. M. Masters and W. P. Ela, Introduction to Environmental Engineering and Science, Prentice Hall, 3rd edition, 2007.

[32] M. E. Al-ahmadi and A. A. El-Fiky, "Hydrogeochemical evaluation of shallow alluvial aquifer of Wadi Marwani, western Saudi Arabia," Journal of King Saud University, vol. 21, no. 3, pp. 179-190, 2009.

[33] A. R. Khanfar, "Dissolved nitrogen in drinking water resources in Al-Mahareth village of Assir-Saudi Arabia," Saudi Journal of Biological Sciences, vol. 17, no. 3, pp. 265-268, 2010.

[34] M. Nabil Alaa El-Din, I. M. Madany, A. Al-Tayaran, A. Hakeem Al-Jubair, and A. Gomaa, "Trends in water quality of some wells in Saudi Arabia, 1984-1989," Science of the Total Environment, vol. 143, no. 2-3, pp. 173-181, 1994.

[35] A. H. Gallardo and N. Tase, "Hydrogeology and geochemical characterization of groundwater in a typical small-scale agricultural area of Japan," Journal of Asian Earth Sciences, vol. 29, no. 1, pp. 18-28, 2007.
[36] D. U. Ophori and J. Toth, "Patterns of ground-water chemistry, Ross Creek Basin, Alberta, Canada," Ground Water, vol. 27, no. 1, pp. 20-26, 1989.

[37] WHO, "Environmental health criteria 224, arsenic and arsenic compounds. Inter-organization programme for the sound management of chemicals," Geneva, Switzerland, 2001.

[38] Ü. Gemici and G. Tarcan, "Hydrogeological and hydrogeochemical features of the Heybeli Spa, Afyon, Turkey: arsenic and the other contaminants in the thermal waters," Bulletin of Environmental Contamination and Toxicology, vol. 72, no. 6, pp. 1107-1114, 2004.

[39] U. Gemici, G. Tarcan, C. Helvaci, and A. M. Somay, "High arsenic and boron concentrations in groundwaters related to mining activity in the Bigadiç borate deposits (Western Turkey)," Applied Geochemistry, vol. 23, no. 8, pp. 2462-2476, 2008.

[40] A. Vengosh, C. Helvac1, and I. H. Karamanderesi, “Geochemical constraints for the origin of thermal waters from western Turkey," Applied Geochemistry, vol. 17, no. 3, pp. 163-183, 2002.

[41] D. E. White, "Active geothermal systems and hydrothermal ore deposits," Economic Geology, vol. 75, pp. 392-405, 1981.

[42] A. S. Sheta, M. S. Al-Sewailem, A. S. Sallam, and A. S. AlMashhady, "Nature and composition of newly formed precipitates in relationship to characteristics of groundwater in arid environment," Arid Soil Research and Rehabilitation, vol. 14, no. 4, pp. 387-401, 2000.

[43] M. J. Kim, J. Nriagu, and S. Haack, "Carbonate ions and arsenic dissolution by groundwater," Environmental Science and Technology, vol. 34, no. 15, pp. 3094-3100, 2000.

[44] W. Sun, R. Sierra-Alvarez, L. Milner, R. Oremland, and J. A. Field, "Arsenite and ferrous iron oxidation linked to chemolithotrophic denitrification for the immobilization of arsenic in anoxic environments," Environmental Science and Technology, vol. 43, no. 17, pp. 6585-6591, 2009.

[45] A. Piqué, F. Grandia, and A. Canals, "Processes releasing arsenic to groundwater in the Caldes de Malavella geothermal area, NE Spain," Water Research, vol. 44, no. 19, pp. 5618-5630, 2010.

[46] S. P. Verma and E. Santoyo, "New improved equations for $\mathrm{Na} / \mathrm{K}, \mathrm{Na} / \mathrm{Li}$ and $\mathrm{SiO}_{2}$ geothermometers by outlier detection and rejection," Journal of Volcanology and Geothermal Research, vol. 79, no. 1-2, pp. 9-23, 1997. 

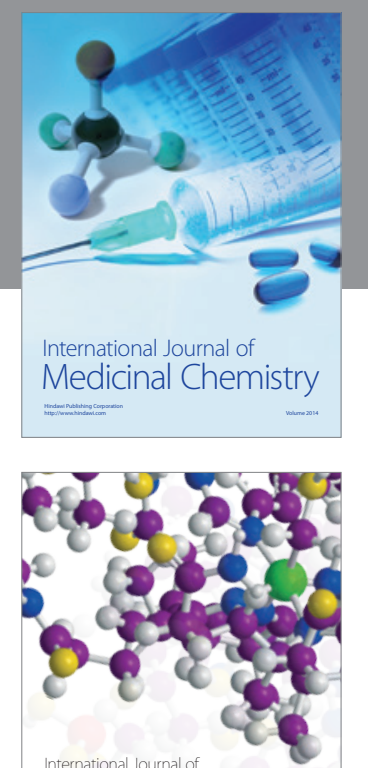

\section{Carbohydrate} Chemistry

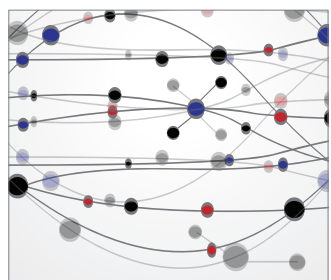

The Scientific World Journal
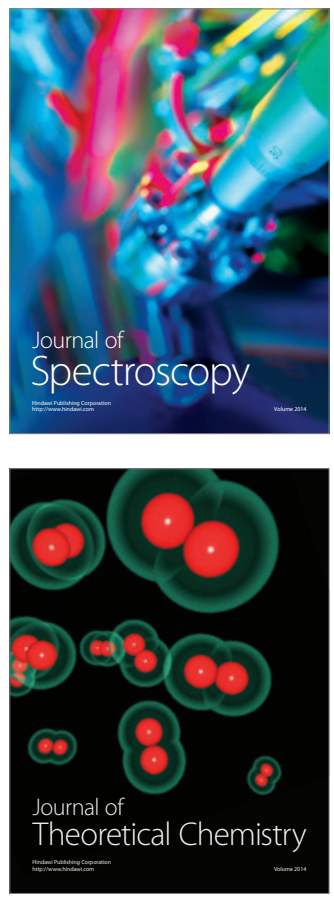
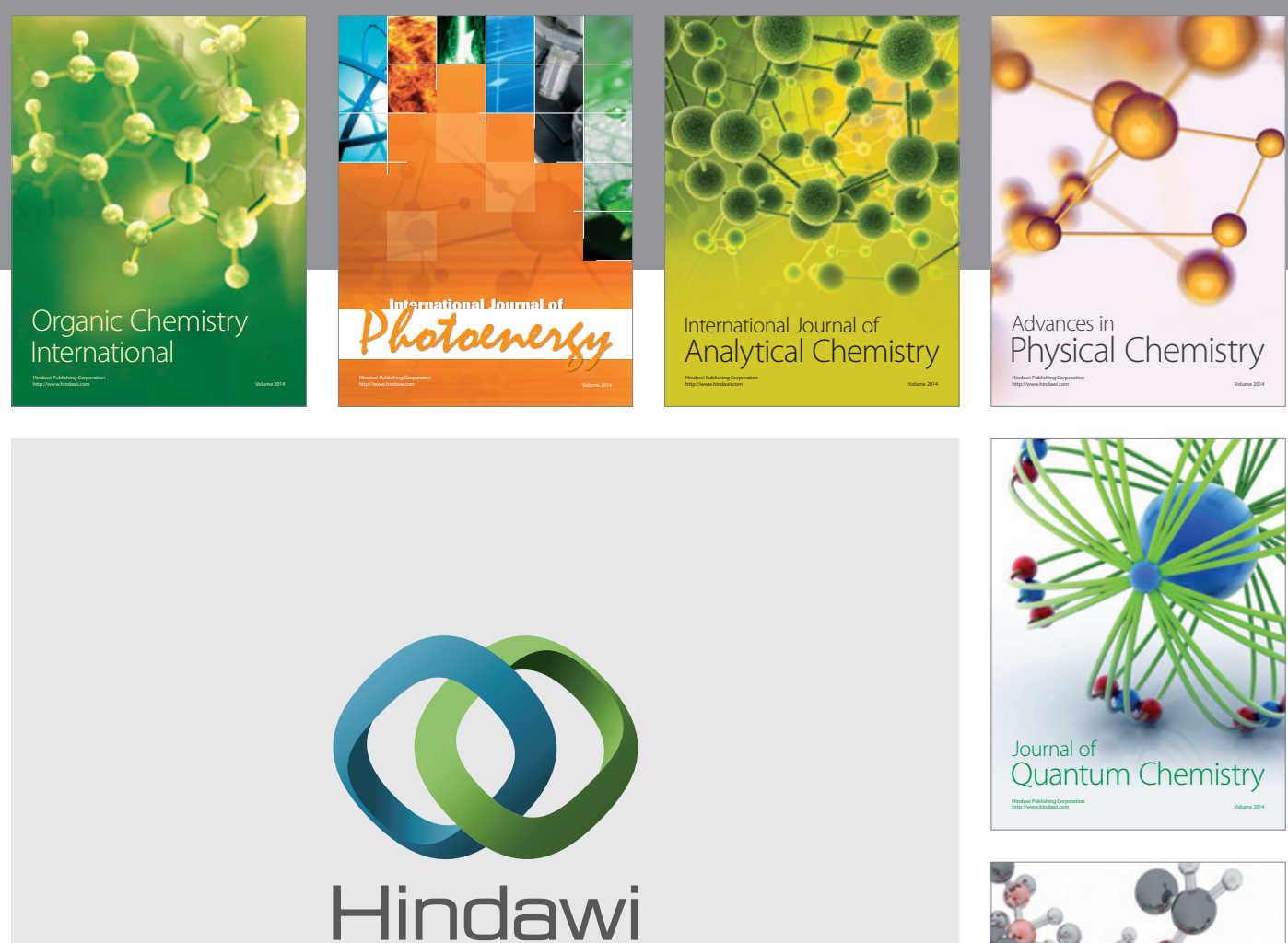

Submit your manuscripts at

http://www.hindawi.com

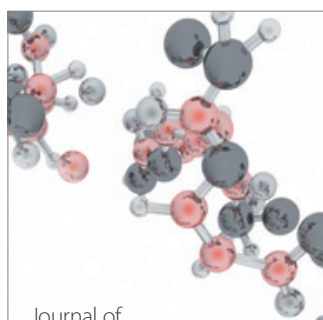

Analytical Methods

in Chemistry

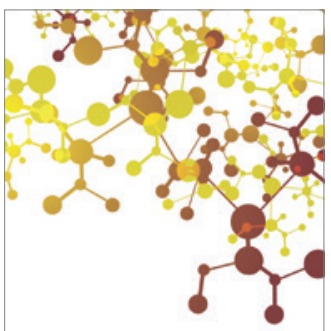

Journal of

Applied Chemistry

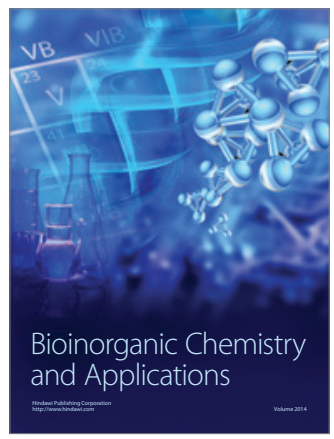

Inorganic Chemistry
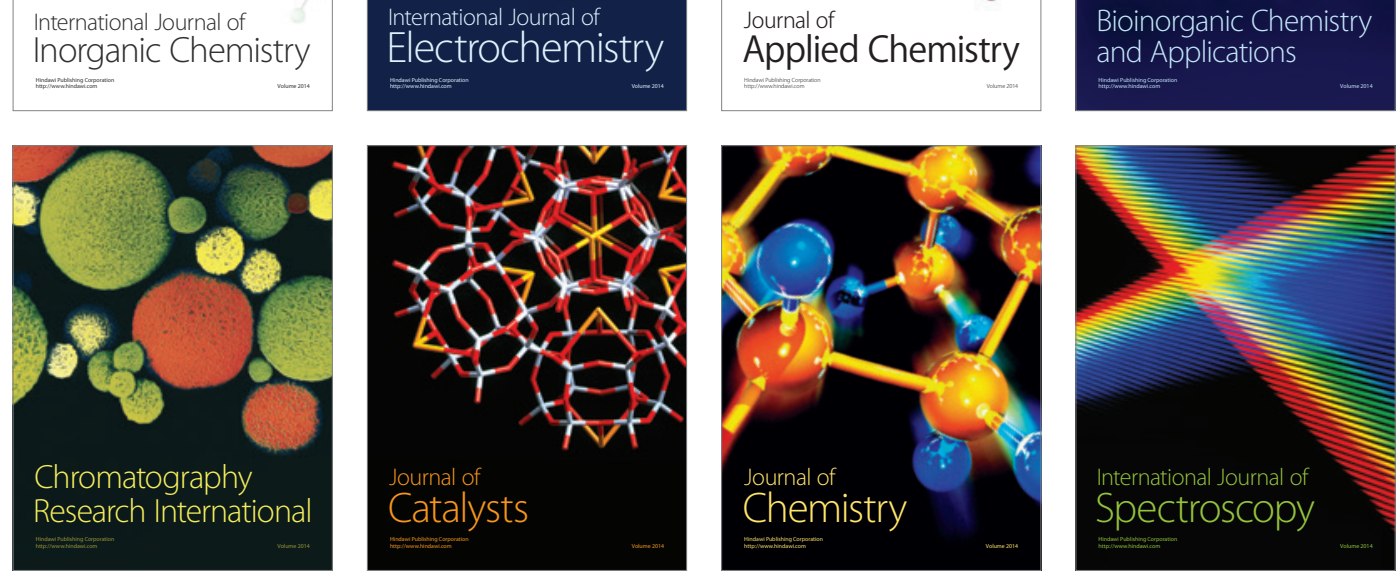